\title{
AN EXPLORATORY ECONOMETRIC ANALYSIS OF SHARED ELECTRONIC BANKING NETWORK ADOPTION
}

\author{
Robert J. Kauffman \\ Yu-Ming wang \\ Information Systems Department \\ Stern School of Business \\ New York University
}

Replaces: Working Paper IS-92-36

Working Paper series

STERN IS-93-25 
Center for Digital Economy Research Stern School of Business

Working Paper IS-93-25 
An Exploratory Econometric Analysis of Shared Electronic Banking Network Adoption

August 31, 1993

Robert J. Kauffman

Associate Professor of Information Systems

Stern School of Business

New York University

Yu-Ming Wang

Doctoral Program in Information Systems

Stern School of Business

New York University

\section{Acknowledgements}

The authors wish to thank Richard Yanak, President, and Richard Symington, Vice President, for financial support, and access to managers, data and the corporate membership of the Yankee 24/New England Network, Inc. electronic banking network. We also thank James McAndrews, currently a senior economist at the Federal Reserve Bank of Philadelphia, for access to data on banking firm characteristics and advice on electronic banking issues. Linda Fenner Zimmer, President, Electronic Banking Economics Society, contributed a wealth of knowledge and insight based on her experience as long-time industry consultant. Phil Ein-Dor provided useful comments on an earlier draft of this paper. All errors in fact and in interpretation are the sole responsibility of the authors. 
Center for Digital Economy Research Stern School of Business

Working Paper IS-93-25 


\title{
An Exploratory Econometric Analysis of Shared Electronic Banking Network Adoption
}

\begin{abstract}
What are the determinants of early interorganizational system (IOS) adoption? This paper focuses on a specific kind of IOS -- shared electronic banking networks -- and employs an economic approach that views adoption and diffusion in terms of cost and benefit. We attempt to identify firm characteristics that are likely to influence the perceived business value of network membership and develop specific hypotheses that can be tested empirically using historical data in a realistic setting. We undertake an exploratory econometric analysis of the adoption of Yankee 24, a large shared electronic banking network in the northeastern United States. Using Bass' analytical diffusion model, we categorize Yankee 24 network members into earlier and later adopters. Probit models are estimated to assess the impact of explanatory variables on shared electronic banking network adoption. The number of branch offices operated by a bank, its total demand deposits, and the proportion of its total deposits accounted for by demand deposits are found to be important predictors of earlier adoption. We find that the number of branch offices operated by a bank, a proxy for the size of its proprietary network, has a negative impact on early adoption, which contradicts the common wisdom that a large firm size is a prerequisite for adoption of technological innovations.
\end{abstract}


Center for Digital Economy Research

Stern School of Business

Working Paper IS-93-25 


\section{Introduction}

Interorganizational systems (IOSs), automated information systems shared by two or more companies (Cash and Konsynski, 1985), are rapidly becoming a competitive necessity in business, and are likely to have fundamental impacts on transactions in a wide variety of industries. For example, the strategic use of electronic data interchange (EDI), a category of IOS, has been suggested to improve a firm's overall operational productivity and to enhance its competitive advantage. Canright (1988) reported that EDI was being used by $75 \%$ of the Fortune 100 and $39 \%$ of the Fortune 500 by January 1988 to perform traditional business communications processes. Although EDI deployment is still in its early stages, market researchers have estimated that the market should observe explosive growth, ranging from $40 \%$ to $80 \%$ of the current installed base through the 1990s.

Several studies have documented successful applications of IOSs, including regionally shared electronic banking networks in the middle Atlantic United States (Banker and Kauffman, 1991; Clemons, 1990), the CIRRUS and PLUS nationally shared electronic banking networks (Kauffman and Wang, 1993), airline computerized reservation systems (CRS) (Copeland and McKenney, 1988), and wholesale distribution systems (Clemons and Row, 1988). Other well known IOSs include the securities settlement system that operates after financial market trades are made (Weiss, 1986), credit card switching and transaction confirmation systems (Steiner and Teixeira, 1990), and the Society for Worldwide Interbank Financial Telecommunications (SWIFT) that has traditionally provided telecommunications links between international commercial banks to permit the exchange of payment information.

Because average costs decrease as the size of operations and transactions volume increase, firms can achieve economies of scale in developing, introducing, and operating networks, and deliver high levels of customer service by offering comprehensive 
geographic coverage. In addition to economies of scale, IOSs often exhibit positive network consumption externalities for network members: the benefit that a member derives from a network increases as other firms join the network (Rohlfs, 1974). Because of scale economies and network externalities, the dynamics of network goods have been suggested to be fundamentally different from those of conventional technological innovations (Katz and Shapiro, 1986a). Markus (1987) argued that communications technologies have characteristics not shared by many other traditional technological innovations, and traditional explanations of diffusion of innovations do not accommodate these characteristics. A recent study by O'Callaghan, Kaufmann, and Konsynski (1992) also points out that the adoption of EDI is significantly different from the adoption of an innovative technology.

IOSs change the nature of competition significantly, and can have a far-reaching impact on the structure of entire industries (Bakos, 1991). To date, however, there have been only few empirical studies examining the factors that influence IOS adoption, and almost none has reported the determinants of IOS adoption employing historical data. This paper focuses on shared electronic banking networks, a subset of IOSs (Johnston and Vitale, 1988), to examine the determinants of adoption. By viewing the adoption and diffusion of shared electronic banking networks primarily in terms of cost and benefit, we attempt to identify firm characteristics that are likely to influence the perceived business value and thus the adoption of a shared electronic banking network at the level of individual banks. We undertake an econometric analysis of the adoption of Yankee 24, the dominant shared electronic banking network in the New England area of the United States. Yankee 24 network members are categorized into earlier and later adopters using Bass' analytical diffusion model (Bass, 1969) as the theoretical basis. Probit analyses are then performed to assess the impact of the determinants of shared electronic banking network adoption, using a data set that includes Yankee 24 adoption data and firm characteristics for banks in our sample. The results are compared with prior work on technology adoption, especially Hannan and McDowell (1984) and Saloner and Shepard (1991), who investigated the adoption of automated teller machines (ATMs) 
without sharing.

The plan of this paper is as follows. Section 2 examines the theoretical basis for adopter categories and reviews prior studies of technology adoption and diffusion to identify factors that may influence IOS adoption. Section 3 begins with a description of IOS adoption in electronic banking, followed by a discussion of the determinants of shared electronic banking network adoption and the development of the study hypotheses. In addition, we argue that firm size is not related to innovativeness by logical necessity. Section 4 describes the Yankee 24 shared electronic banking network, sample and data collection, and presents the results of the econometric analysis. The conclusions of this study and discussions follow.

\section{Prior Research}

Although some work has focused on the adoption of IOSs, in general, and ATM technology, in particular, there has been very little research done on the adoption of shared electronic banking networks. We draw on prior research on adoption and diffusion of traditional technological innovations, which has dealt with issues such as the growth pattern of adoption, the categorization of adopters, and the individual adoption process.

\subsection{Adopter Categories}

Historically, innovation diffusion research has centered on innovativeness and related variables, especially the characteristics of earlier versus later adopters (Brancheau and Wetherbe, 1990). The most widely accepted method of categorizing innovation adopters was proposed by Rogers (1983). The method assumes that the non-cumulative adopter distribution over time takes the form of a bell-shaped curve. Rogers' 
classification results from the division of the normal adopter distribution into categories based on mean time of adoption and the standard deviation of those times. The classification scheme includes five adopter categories: (1) innovators (the first 2.5\%), (2) early adopters (13.5\%), (3) early majority (34\%), (4) late majority (34\%), and (5) laggards (16\%). They are illustrated in Figure 1.

Rogers' categorization, however, has limitations. Mahajan, Muller, and Srivastava (1990) pointed out that the assumption that all innovations follow a normally-distributed diffusion pattern is questionable. And, in spite of the method's simplicity, Rogers provided no empirical or analytical justification of why the size of the adopter categories should be the same for all innovations. We think this is an important issue in the context of innovations that exhibit network externalities. Various authors have pointed to the existence of network externalities that are associated with some kinds of technological innovations, such as railroad track gauges, VCR standards, microcomputer operating systems, and computer microprocessors (Farrell and Saloner, 1985 and 1986; Katz and Shapiro, 1985, 1986a and 1986b). As a result, the adoption path may be skewed or disrupted: (1) there may be a prolonged period of adoption inertia as competing firms play a "wait-and-see" adoption game; or (2) there may be a wholesale rush to adopt. This is called the bandwagon effect by economists; it results when firms perceive that there are industry-wide expectations that one alternative will be selected, thereby making it an industry standard.

Mahajan, Muller, and Srivastava further proposed using Bass' diffusion model as a basis for adopter categorization. Their proposal subsumes the advantageous features of Rogers' method and resolves some of its limitations. Instead of arbitrarily dividing the adopter distribution into a number of categories, the authors exploit certain unique analytical properties of Bass' diffusion model to generate adopter categories in which the shape of the adopter distribution is data-specific (captured by the coefficients of diffusion models). The real contribution here is that one can make inter-study comparisons based on common values of diffusion model parameters describing the adopter distribution. 
Figure 1. Rogers' Adopter Categories

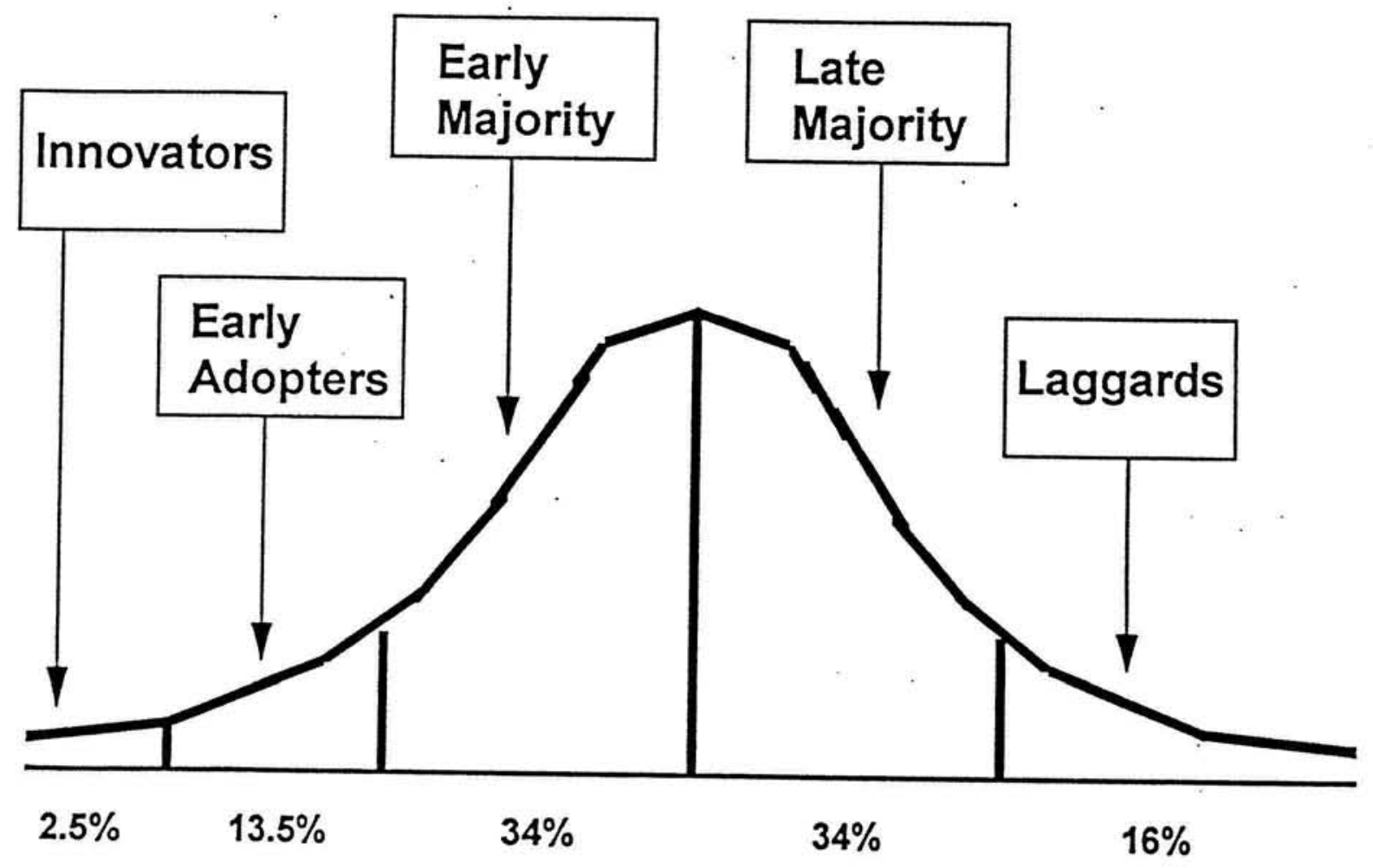


The S-shaped cumulative adopter distribution, $F(t)$, from Bass (1969), is given by:

$$
\mathrm{F}(\mathrm{t})=\left(1-\mathrm{e}^{-(\mathrm{p}+\mathrm{q}) \mathrm{t}}\right) /\left(1+(\mathrm{q} / \mathrm{p}) \mathrm{e}^{-(\mathrm{p}+\mathrm{q}) \mathrm{t}}\right)
$$

where $\mathrm{p}$ is referred to as the coefficient of innovation and $\mathrm{q}$ is the coefficient of imitation. The expression for the time interval of early adoption is:

$$
\mathrm{T}_{1}=-\ln [(2+\sqrt{ } 3) \mathrm{p} / \mathrm{q}] /(\mathrm{p}+\mathrm{q})
$$

It defines those who adopt up to the end of time interval $\mathrm{T}_{1}$ as earlier adopters (either innovators or early adopters). Table 1 summarizes the analytic expressions for the time interval and size of adopter categories based on Bass' diffusion model. Once the values of $\mathrm{p}$ and $\mathrm{q}$ are derived by fitting the cumulative adopter distribution expressed in Equation (1), $T_{1}$ can be estimated. Mahajan, Muller, and Srivastava (1990) further examined the diffusion of personal computers and showed that the adopter categories based on the Bass model can be used to study differences among their profiles.

Table 1. The Bass Model: Analytical Expressions for Adopter Categories

\begin{tabular}{||l|l|l|l||}
\hline $\begin{array}{l}\text { Adopter } \\
\text { Category }\end{array}$ & $\begin{array}{l}\text { Time Internal Covered } \\
\text { in Adopter Distribution }\end{array}$ & $\begin{array}{l}\text { Expression for } \\
\text { Time Interval }\end{array}$ & $\begin{array}{l}\text { Expression for the } \\
\text { Adopter Category Size }\end{array}$ \\
\hline Innovators & $\begin{array}{l}\text { Initiation of the } \\
\text { diffusion process }\end{array}$ & -- & $p$ \\
\hline $\begin{array}{l}\text { Early } \\
\text { Adopters }\end{array}$ & Up to $\mathrm{T}_{1}$ & $\begin{array}{l}-[1 /(p+q)]^{*} \\
\ln \left[(2+\sqrt{ })^{*} p / q\right]\end{array}$ & $\begin{array}{l}.5^{*}(1-p / q) \\
-\left(1 / \sqrt{ } 12^{*}(1+p / q)\right)-p\end{array}$ \\
\hline $\begin{array}{l}\text { Early } \\
\text { Majority }\end{array}$ & $\mathrm{T}_{1}$ to $\mathrm{T}^{*}$ & $\begin{array}{l}{[1 /(p+q)]^{*}} \\
\ln [(2+\sqrt{ } 3)]\end{array}$ & $1 / \sqrt{ } 12 *(1+p / q)$ \\
\hline $\begin{array}{l}\text { Later } \\
\text { Majority }\end{array}$ & $\mathrm{T}^{*}$ to $\mathrm{T}_{2}$ & $\begin{array}{l}{[1 /(p+q)]^{*}} \\
\ln [(2+\sqrt{ } 3)]\end{array}$ & $1 / \sqrt{ } 12 *(1+p / q)$ \\
\hline Laggards & $\begin{array}{l}\mathrm{T}_{2} \text { until innovation is } \\
\text { replaced }\end{array}$ & -- & $\begin{array}{l}.5 *(1+p / q) \\
-\left[(1 / \sqrt{ } 12)^{*}(1+p / q)\right]\end{array}$ \\
\hline
\end{tabular}

Note: $p$ is referred to as the coefficient of innovation and $q$ is the coefficient of imitation. 
This approach can be employed to investigate differences between earlier and later adopters of a shared electronic banking network. By using network membership adoption data, we can categorize the adopters by fitting the cumulative adopter distribution (expressed in Equation (1)) to obtain $T_{1}$, instead of arbitrarily dividing the adopter distribution into two categories. Those banking firms that adopted before $T_{1}$ are categorized as earlier adopters; all others are later adopters.

\subsection{Factors Influencing IOS Adoption and Diffusion}

At the general level, two approaches, diffusion theoretic and economic, inform innovation diffusion research (Attewell, 1992), although there are other perspectives in studying technology adoption and diffusion. The diffusion theoretic approach views diffusion as a process of communication and influence whereby potential users become informed about the availability of new technology and are persuaded to adopt, through communication with prior users (Rogers, 1983). Thus, firms closely connected to users of an innovation learn about it and adopt it early on, whereas firms at the periphery of communication networks are slower to adopt. In other words, the dominant explanatory variable for the spread of technological innovations emphasizes processes of influence and information flow, and researchers have examined the roles of persons and patterns of communication and influence within the adopting firm (Attewell, 1992). Brown (1981), however, criticized the view of adoption as primarily the outcome of a learning or communication process because it emphasizes demand for an innovation by potential adopters, limited only by their innovativeness.

Innovation adoption and diffusion research from a behavioral perspective suggests that the adoption of innovations is related to the attributes of the innovations as perceived by potential adopters. In particular, the degree to which an innovation is perceived as being better than the idea it supersedes has a direct impact on the likelihood of adoption (Rogers 1983). Of these attributes, relative advantage and compatibility with present systems have been cited as the most important attributes 
(Tornatzky and Klein, 1982). In a recent field survey of EDI adoption, O'Callaghan et al. (1992) examined the adoption of a particular form of EDI, the computer-based interface offerings by insurance carriers to their independent agent communities. They argued that variance in firm-level adoption of EDI should reflect differences in the perceived relative advantage of EDI. Using multiple measures for the proposed constructs in a field survey, they found that the target firm's perception of the costs and benefits of EDI linkage are the most crucial inputs in its decision whether to adopt the EDI technology. However, they are not able to find any positive impact of influence wielded by other adopting agents, source firm, or formal industry structures on the decision to adopt an EDI linkage.

The sociopolitical approach is concerned about power, dependence, and conflict (Gaski, 1984). In particular, this approach examines the social and political forces and their impact on inter-organizational relationships. It is argued that a firm forms interorganizational linkages primarily to gain control over critical resources and thereby reduce uncertainty in their acquisition. Although there is some evidence that suggests power relationships between participating firms in an IOS can have a significant impact on EDI, this approach seems less applicable in the context of shared electronic banking networks, the ownership of which is typically shared and where there is no buyer-supplier type relationship

In a study of technology adoption in the commercial banking industry, Pennings and Harianto (1992) examined the propensity of banks to adopt a specific new form of information technology: video banking services (referred to as videotex), a computerbased interactive system that electronically deliver screen text, numbers and graphics. They found support for their hypothesis that prior experience in information technology and interfirm linkages with extramural sources of technology are important precursors to innovation and crucial for explaining banks' decision to adopt videotex. Firm size, however, also predicts the odds of entering the videotex industry. It is likely that firm size is correlated with the authors' measure of prior experience with information 
technology and with interfirm linkages, and thus it acts as a workable surrogate.

Studies of technology adoption and diffusion using the approaches discussed above are numerous. Many of them have attempted to identify factors that influence adoption and diffusion using subjective measures for some proposed constructs, and thus may be subject to measurement problems. The economic approach, on the other hand, views diffusion primarily in terms of cost and benefit. In general, the economics literature posits, ceteris paribus, that the length of time a firm waits to adopt a technique is inversely related to the profitability of the installation. In other words, the higher the cost, the slower diffusion will occur, and the higher the perceived profit from an innovation, the faster adoption will occur.

The most widely tested theory of the diffusion of innovation was advanced by Mansfield (1968). His main theory consists of two points: (1) the diffusion of an innovation throughout an industry follows a logarithmic curve, which is a function of the relative profitability of the innovation and the initial investment required; and (2) the rate of diffusion is more rapid in more competitive industries.

Romeo (1977) provided a further test of the usefulness of the model of the imitation process developed by Mansfield. He investigated how the characteristics of the early users of numerical control machines differed from those that were slower to use them. Firm size, profitability of the innovation to the firm, and progressiveness of management were identified as the factors that were most likely to influence whether or not a firm would use the innovation. Because the profitability of the installation for each firm could not be obtained and the progressiveness of management was not adequately measured, only firm size was found to be important.

Davies (1979) argued that Mansfield's model is too mechanistic. It has little to say about the nature of the adoption decision at the firm level, where there may be major differences between firms in their expectations of how profitable an innovation will be. 
Further, the lag before adopting the innovation probably will differ significantly -- even among firms of the same size within the same industry.

Hannan and McDowell (1984) used data on the adoption of ATMs by banking firms to examine the relationship between the decision to adopt new technology and the determinants of that decision. They found that larger banks, banks operating in more concentrated local banking markets, and banks that were part of bank holding company organizations evidenced a higher probability of adoption of ATM technology. Little sharing of electronic banking assets occurred at that time, however: ATMs had just been introduced. With more widespread use of ATMs in the banking industry, the trend has been toward shared electronic banking networks, and toward network consolidation and interstate banking. (Felgran and Ferguson (1986) and McAndrews (1991) provide useful reviews of shared banking network evolution).

Saloner and Shepard (1991) employed an econometric model to test the impact of explanatory variables on the timing of ATM adoption among banking firms in the U.S. They found that a bank's date of adoption is earlier the larger the number of its branches (a proxy for the proprietary network benefits to the bank in adopting ATM) and the larger the value of its deposit base (a proxy for the number of users). Again, because there was little sharing of ATMs in the time frame of their study, the focus was on the benefits of adoption in the presence of proprietary ATM network effects.

Although many studies have attempted to ascertain the effect of profitability on the firm's adoption decision, most of them have been largely unsuccessful, probably due to measurement problems (Jensen, 1982). We employ an economic approach to IOS adoption, and attempt to identify firm characteristics that may influence the business value of network adoption to a potential adopting firm and thus its adopting decision. Those firm characteristics can be adequately measured and their impact can be assessed using historical data in a realistic setting. 


\section{Shared Electronic Banking Network Adoption and Hypotheses}

In this section, we identify key factors that are likely to influence managers' shared electronic banking network adoption decision. We focus on the impact of firm characteristics on the net benefits of adopting the shared network and thus on the probability of early adoption. The basic hypothesis is that the adoption of a shared electronic banking network is a rational economic decision: the greater the perceived business value of network membership, the earlier the adoption. To facilitate the discussion of key variables that contribute to the net benefits of network adoption and the development of hypotheses, we begin with a brief description of IOS adoption in electronic banking.

\subsection{IOS Adoption and Diffusion in Electronic Banking}

ATMs are used to provide electronic banking services to bank customers. However, they involve expensive telecommunications and computer technology. Thus only large banking firms with a large transaction volume can justify installing ATMs or establishing ATM networks by spreading the costs and taking advantage of scale economies. Because of their comprehensive geographic coverage, the larger the installed base of an ATM network, the more attractive it is to customers.

To protect themselves from losing market share to the bigger banks in the market, many depository financial institutions have turned to shared electronic banking networks, in which each participant only needs to make a small amount of investment in electronic banking on-site. Shared ATM networks allow one bank's customer to access an account using ATMs owned by other network members at locations that are convenient for the customer at a given time. By joining shared electronic banking networks, therefore, smaller banking firms are able to offer their customers a higher density of ATM locations and greater access to their bank accounts, at the same level that large banking firms can 
provide -- without the corresponding capital costs. Finally, some owners of proprietary networks recognize that they may not be able to offer the same locational convenience as shared electronic banking networks, and may have begun to join shared electronic banking networks in order to generate more revenue and remain competitive.

Figure 2 presents a typical shared electronic banking network, involving three banks, A, B, and C. The shared network organization serves as the switch in the network, linking member banks' ATMs to a central switch that routes a transaction from the ATM used by a card holder to the card holder's bank (McAndrews, 1992). The switch may route the transaction to the appropriate bank, the bank issuing the card used for the transaction, for processing, or it may do all processing itself. In either case, accounting for transfer of funds between banks, and for fees charged for use of other banks' ATMs, are also processed by the switch (Clemons, 1990). Smaller banks such as Bank $\mathrm{C}$ can use the ATM processing services provided by other banks or third-party vendors that sell ATM management capabilities to gain processing capability.

Figure 2. Typical Shared Electronic Banking Network

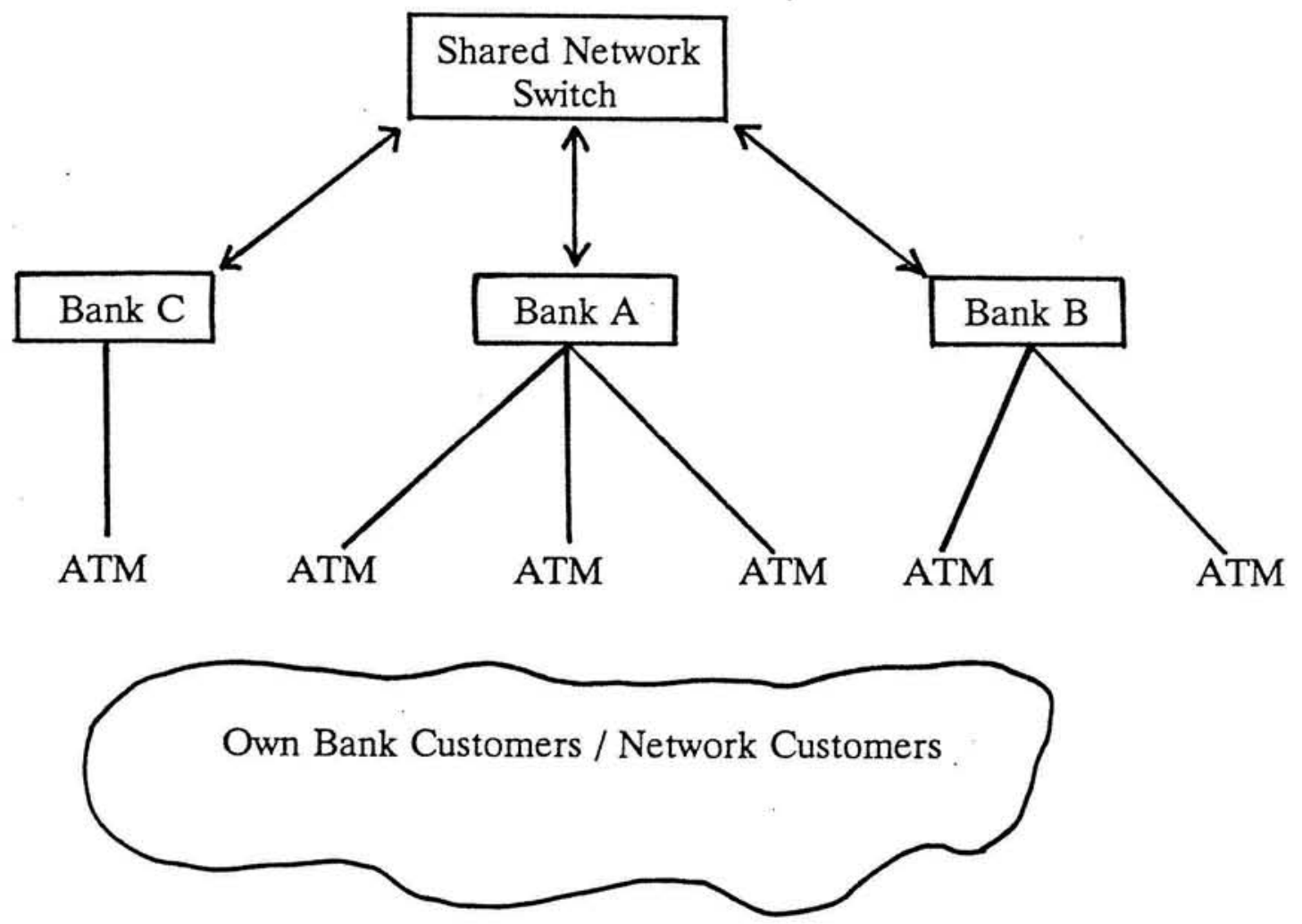


In general, there are three types of network ATM transactions, summarized in Table 2. Us-on-us refers to the use of a bank's ATMs by its own card holders, for example, the use of Bank A's ATMs by its card holders. Such transactions typically are not routed through the shared network's switch, and usually are processed within the card holder's bank. Others-on-us refers to the use of a bank's ATMs by card holders from other banks. Us-on-others refers to the use by a bank's card holders of another bank's ATMs. For example, when Bank C's card holders access their accounts using Bank A's ATMs, the transactions initiated are others-on-us to Bank A, but us-on-others to Bank C. Us-on-us transactions provide a minimum level of electronic banking services demanded by customers. Us-on-others and others-on-us represent additional transactions that require interchange. In each case, the research evidence has shown that customers are willing to pay for the additional banking services and locational convenience (Banker and Kauffman, 1991; McAndrews, 1992).

Table 2. Typical ATM Transactions in Shared Electronic Banking Networks Types of Transaction Brief Description Us-on-us The use of a bank's ATMs by its card holders.

Others-on-us The use of a bank's ATMs by card holders from another bank.

Us-on-others

The use by a bank's card holders of another bank's ATMs.

\subsection{The Determinants of Network Adoption and Hypotheses}

Several firm characteristics are likely to be important determinants of technology adoption. In particular, much of the theoretical and empirical diffusion research suggests that firm size plays an important role in decisions to adopt new technologies (Rose and Joskow 1990). In fact, a substantial part of the variation in technology adoption in 
previous research can be explained by interfirm differences in size (Mansfield, 1968), and the data point to a positive relationship between early adoption and firm size. For example, Hannan and McDowell (1984) found that larger banks evidenced a higher probability of adoption of ATMs.

There are many reasons why large firms tend to be early adopters. They may have more resources available to finance an investment, may be better able to take the risks, and may expect the technology to be more profitable than their smaller rivals (Mansfield, 1993). Hence, the costs and risks of early adoption are more easily borne by large firms. Size itself, however, is not related to innovativeness by logical necessity; it becomes significant only when it implies or indicates the conceptual variables that are important in themselves (Mohr, 1982). In other words, size may also have indirect effects because it can be a surrogate for many other potential explanatory variables and may not contribute to the benefits of adoption directly. It is likely to lead directly to scale economies which enhance the feasibility of adoption such that larger firms can justify adoption of new technology. It is also likely that size is correlated with accumulated experiences and technological skills, or what Cohen and Levinthal (1990) call absorptive capacity which diminishes the threshold for extracting know-how from others.

Irrespective of size, any of a number of firm characteristics may make a new technology profitable and desirable for one company, but not for another. In other words, differences in characteristics among firms might be a potential source of business value or competitive advantage in the adoption of technology. In the remaining sections, we discuss several firm characteristics that may contribute to the net benefits of adoption and thus increase the probability of early adoption. We analyze the net benefits to a potential adopting bank in terms of the benefits and costs of network adoption, expressed as a function of bank characteristics. On the cost side, we consider the opportunity costs associated with the adoption of a shared network. On the benefit side, we consider revenues increase due to enhancement in customer account access convenience. We 
assume that banking firms.are generally able to estimate the economic benefits associated with the adoption of a shared electronic banking network, and use it as a basis for making network adoption decisions. In other words, the greater the perceived business value of network membership, the earlier the adoption.

Saloner and Shepard (1991) argued that the proprietary network benefits to a bank's customer is an increasing function of the number of ATMs the bank has deployed as a result of being able to access her account more conveniently. Thus, the network benefits to the bank is also increasing in the number of ATMs deployed. In the context of shared electronic banking network, however, there may be opportunity costs for banks that have proprietary ATM networks prior to shared network membership because they already enjoy internally generated network benefits. Thus, banking firms with a large proprietary ATM network are not necessarily willing to jump right into a shared electronic banking network, letting all other members share the large number of ATMs that they contribute.

The classic example of this in the United States is Citibank, which initially deployed the largest proprietary electronic banking network in the New York City area, and has come to be recognized as a leader in the production of innovative electronic banking hardware and software. (For example, today Citibank deploys touch screen technology-based ATMs that can handle five different languages: English, Spanish, Chinese, Greek and Korean.) As a result of this deployment, Citibank was able to increase its deposit market share from $4 \%$ to $13.4 \%$ of the New York Metropolitan market total, the largest share of the richest banking market in the country (Glaser, 1988), fueling its expansion throughout the 1980s. All the way until 1992, the bank steadfastly resisted efforts by the major national networks, CIRRUS and PLUS, to share its network.

Banks with small ATM networks, however, may have low opportunity costs, but greater motivation to join a shared network to achieve economies of scale or reach out 
geographically to enhance customer coverage, particularly when the current trend toward more efficient third-party processors is already helping to solve the technology dilemma for small and medium-sized banks (Croxford, 1988). In addition, they may view shared networks as a mechanism to avoid competitive disadvantage.

Thus, we expect the opportunity costs for a bank to be increasing in the size of its own ATM network, and banks with a large ATM network are likely to adopt later. On the other hand, banks with few or no ATMs are more likely to adopt early. We use the number of bank branches operated by a bank as a proxy for the number its ATMs because branch offices are the most common and lowest cost locations for ATMs (Saloner and Shepard, 1991). Thus, we have the following hypothesis:

Hypothesis 1: The smaller the number of a bank's branch offices, the more likely will be earlier adoption of a shared network.

As described earlier, the benefits of a shared electronic banking network to a bank's depositor as a result of being able to access her account more conveniently can lead to increase in revenues to the bank, which can be assumed to be proportional to the value increase to the depositors. Thus, the benefits of shared network adoption for a bank should be increasing in the number of its depositors. In other words, we expect that the larger the number of a bank's depositors, the greater the perceived business value of network adoption, and thus the more likely will be earlier adoption. We use total dollar amount of demand deposits as a proxy for the number of bank depositors that demand ATM services.

Hypothesis 2: The larger a bank's total demand deposits, the more likely will be earlier adoption of a shared network. 
Finally, banks whose depositors demand more ATM services may find greater value in shared network membership. In other words, a bank that is more retail-oriented may value a shared network more highly and adopt earlier because its depositors tend to use network ATM services more often, which results in revenue increase to the bank. Because cash withdrawals from checking accounts represent the most common transaction performed with ATMs (Hannan and McDowell, 1984), we include a measure of product mix defined as the proportion of the bank's total deposits accounted for by demand deposits to capture the extent of its retail orientation. We expect that banks specializing more in retail banking will find shared network services relatively more attractive.

Hypothesis 3: The higher the ratio of demand deposits to total deposits, the earlier will be the adoption of a shared network.

In summary, the net benefits, II, from shared network adoption for a bank can be expressed in the following function:

$$
I I=f\left(N_{A T M} N_{D E P O S I T O R} M I X\right)
$$

The net benefit function is increasing in $N_{D E P O S I T O R}$, the number of depositors that demand ATM services, and $M L X$, the extent of retail orientation. However, the function is decreasing in $N_{A T M}$, the number of a bank's ATMs deployed in its proprietary ATM network. Thus, banks with high values of $N_{D E P O S I T O R}$ and $M I X$ will tend to adopt earlier, while a high value of $N_{A T M}$ will have a negative impact on early adoption. 


\section{Method and Results}

This section describes the research site, sample, data collection and measurement. In addition, we discuss the categorization of our sample into earlier and later adopters and present the results of the econometric analysis.

\subsection{Research Site}

New England Network Inc., the Connecticut-based owner of the Yankee 24 shared electronic banking network, allowed us to have access to their member list and adoption data. Yankee 24 was founded by nine banking firms in 1983 to establish a regionally shared network. In July 1984, the network went into operation, and began to seek other banking firm members. At the time, state regulatory policies for shared ATM networks in Connecticut ruled that ATMs were not branches and that ATM sharing should be mandatory, requiring membership to be open to all depository institutions in Connecticut with all members sharing ownership of the non-profit network organization. Thus, potential entrants could become members by requesting to join Yankee 24. Outof-state banks, however, were prohibited from establishing or using ATMs within the state at that time.

Each participating bank paid a one-time membership fee of $\$ 5,000$, a terminal hook-up fee of $\$ 300$ per ATM, and an ongoing monthly fee of $\$ 35$ per ATM. Yankee 24 , the network operator, is responsible for overall network strategy for marketing and advertising. Services offered by the network include withdrawal, deposits, transfers, and cash advances. In 1985, Yankee 24 became the largest shared electronic banking network in New England in terms of number of ATMs shared and interbank ATM transactions. By 1987, Yankee 24 had 127 members and 789 ATMs in the network. In February 1987, banking firms in other New England states were allowed to join the shared network organization, and the network's marketing staff began to actively solicit 
new members in those states. By the time of this study, Yankee 24 had grown to be the dominant shared electronic banking network in New England. It included more than 700 network members, and more than 4,000 ATMs accessible to all members' ATM card holders.

\subsection{Sample, Data Collection and Measurement}

Our data set includes Yankee 24 membership data and firm characteristics for banks in the New England area. Network adoption data were obtained from New England Network Inc. Banking firm characteristics were obtained from periodic reports, including the Report of Condition and Income (referred to in the banking industry as a "call report") and the Summary of Deposits (SUMD) maintained by the Federal Reserve Board. Additional information related to bank branches and locations was obtained from Polk’s Bank Directory (1987).

A list of 1448 banking firms that operated in the New England area was obtained from the Federal Reserve Bank of Philadelphia. Because Yankee 24 started in Connecticut in 1984 but banking firms in other New England states were allowed to join the shared network only after 1987, earlier adopters were essentially in Connecticut. Therefore, we divided all banking firms in our sample into two groups, one for those based in Connecticut and one for all others in New England. To focus on the adoption and diffusion of Yankee 24 after it was established, the founding members were excluded from our sample, yielding a total of 1439 banking firms, 484 in Connecticut and 955 in other New England states.

Explanatory variables that are present in our data set include: (1) the number of a bank's branch offices (coded as BRANCH_NETWORK), as a proxy for the size of its proprietary network; (2) demand deposits as a percentage of total deposits (coded as PRODUCT_MIX), a proxy for a bank's retail orientation; and (3) the log of total demand deposits (coded as DEMAND_DEPOSITS, with the logarithm used because the 
distribution of demand deposits is skewed), a proxy for the number of depositors that may demand ATM services. Table 3 summarizes these variables. Table 4 presents descriptive statistics for our sample in Connecticut and upper New England.

Table 3. Definitions of Variables

\begin{tabular}{ll}
\hline \hline Variable Name & Variable Definition \\
\hline BRANCH_NETWORK & The number of branch offices operated by a bank. \\
DEMAND_DEPOSITS & The log of total demand deposits. \\
PRODUCT_MIX & $\begin{array}{l}\text { Product mix, defined as the ratio of number of dollar } \\
\text { amount of demand deposits and dollar amount of total } \\
\text { (demand plus time) deposits. }\end{array}$ \\
\hline \hline
\end{tabular}

Table 4. Sample Descriptive Statistics

\begin{tabular}{lllll}
\hline \hline & \multicolumn{2}{c}{ Connecticut } & \multicolumn{2}{c}{ Upper New England } \\
Variables & Mean & S.D. & Mean & S.D. \\
\hline BRANCH_NETWORK & 2.897 & 10.586 & 3.914 & 6.973 \\
DEMAND_DEPOSITS & 7.828 & 2.476 & 8.653 & 2.617 \\
PRODUCT_MIX & 0.040 & 0.096 & 0.095 & 0.148 \\
\hline \hline
\end{tabular}

" standard deviation.

\subsection{Results}

To categorize banking firms in our sample into earlier and later adopters, we employ the classification scheme proposed in (Mahajan, Muller, and Srivastava, 1990), which makes use of the analytical properties of the Bass diffusion model. Using annual growth data on 
Yankee 24 members in Connecticut, we estimate the cumulative adopter distribution formula presented in Equation (1) using non-linear least squares estimation. The coefficients $p$ and $\mathrm{q}$ in Equation (1) are .115 and .685, respectively: both are significant at the .01 level, and the adjusted $\mathrm{R}^{2}$ of the model is .982 . Recall that $\mathrm{p}$ is the coefficient of innovation and $\mathrm{q}$ is the coefficient of imitation. Using the estimated coefficients to calculate $T_{1}$, the time interval of early adoption expressed in Equation (2), we obtain a value for $T_{1}$, which is equivalent to 7 months after Yankee 24 started. For our sample in other New England states, we also estimate the cumulative adopter distribution formula using the associated Yankee 24 annual member growth data. A p value of .092 and a q value of .45 are obtained, both significant at the .01 level with the adjusted $\mathrm{R}^{2}$ of .991 . These coefficients translate to a $T_{1}$ value of .51 , i.e., 6 months after Yankee 24 crossed the Connecticut state boundary.

In sum, for our sample in Connecticut, those firms which adopted Yankee 24 earlier than March 1985 are categorized as earlier adopters, and all others as later adopters. As a result, $21.9 \%$ of the Connecticut-based banking firms are in the earlier adopter category. For our sample in other New England states, those firms which adopted Yankee 24 before August 1987 are categorized as earlier adopters, and all others as later adopters. Thus, $16.1 \%$ of the banking firms in New England in our sample are in the earlier adopter category. Table 5 presents a distribution of our sample and adopter categories.

Table 5. Distribution of Sample and Adopter Categories

\begin{tabular}{lcc}
\hline \hline Area & Number of Firms & Earlier Adopters \\
\hline \hline Connecticut & 484 & 106 \\
Upper New England & 955 & 153 \\
Total & 1439 & 259 \\
\hline \hline
\end{tabular}


To examine the impact of the explanatory variables on the relative innovativeness of shared network adoption, we undertake separate analyses for our sample in Connecticut and other New England states. Because Yankee 24 network members are categorized into earlier and later adopters, the model we consider employs a binary dependent variable, coded as 0 and 1 , for later adopters and earlier adopters, respectively. Due to the presence of the value-limited dependent variables, straightforward regression analysis is not able to provide unbiased estimates of the model parameters, and thus is not readily applicable (Greene, 1990). Instead, the probit model, frequently used in econometric analysis of models involving discrete choices, is employed for this purpose.

For our sample in Connecticut, the probit model estimated is significant at the .01 level. All independent variables but PRODUCT_MIX are significant at the .10 level. The estimated coefficients suggest that DEMAND_DEPOSITS and PRODUCT_MIX have a positive impact, while BRANCH_NETWORK has a negative impact on early adoption, as expected. For our sample in other New England states, the probit model itself as well as all independent variables are significant. Consistent with the estimation results for Connecticut, PRODUCT_MIX and DEMAND_DEPOSITS have a positive impact, while BRANCH_NETWORK registers a negative impact on early adoption. Table 6 summarizes the estimation results for the state of Connecticut.

Both probit models indicate that the number of branch offices operated by a bank, its total demand deposits, and the proportion of its total deposits accounted for by demand deposits are important predictors of earlier adoption. It appears that the number of a bank's branch offices, a proxy for the size of its proprietary network, has a negative impact on early adoption. 
Table 6. Probit Model Estimation Results

\begin{tabular}{|c|c|c|c|c|}
\hline \multirow{3}{*}{$\begin{array}{l}\text { Variables } \\
\text { BRANCH_NETWORK }\end{array}$} & \multicolumn{2}{|c|}{$\underline{\text { Connecticut }}$} & \multicolumn{2}{|c|}{ Upper New England } \\
\hline & $\begin{array}{l}\text { Coeffici } \\
\text { (Standarc }\end{array}$ & t-ratio & $\begin{array}{l}\text { Coefficient } \\
\text { (Standard error) }\end{array}$ & t-ratio \\
\hline & $\begin{array}{c}-0.017 \\
(.010)\end{array}$ & $-1.719^{\circ}$ & $\begin{array}{l}-0.020 \\
(0.008)\end{array}$ & $-2.278^{* *}$ \\
\hline DEMAND_DEPOSITS & $\begin{array}{l}0.409 \\
(.052)\end{array}$ & $7.950^{\cdots}$ & $\begin{array}{c}0.222 \\
(0.030)\end{array}$ & $7.366^{* *}$ \\
\hline PRODUCT_MIX & $\begin{array}{l}1.002 \\
(.854)\end{array}$ & 1.170 & $\begin{array}{c}0.685 \\
(0.354)\end{array}$ & $1.940^{* *}$ \\
\hline Constant & $\begin{array}{c}-4.877 \\
(.492)\end{array}$ & $-9.923^{\cdots}$ & $\begin{array}{l}-3.061 \\
(0.267)\end{array}$ & $-11.450^{-}$ \\
\hline
\end{tabular}

\section{Conclusions and Discussions}

In this section, we present the conclusions of this study, and discuss the limitations and possible extensions for future research.

\subsection{Conclusions}

Using electronic banking as a context, we examine the determinants of early IOS adoption. We employ an economic approach that views adoption primarily in terms of the perceived network business value, which is expressed as a function of key firm characteristics. By estimating simple econometric models using a data set that includes Yankee 24 adoption data and banking firm characteristics, we examine differences between 
earlier and later adopters to gauge the impact of the determinants of network adoption.

The results support our hypotheses that the smaller the number of branch offices, the more total demand deposits, and the higher the ratio of demand deposits over total deposits, the earlier the adoption of shared electronic banking networks. Thus, the empirical results tend to support a perceived net benefit function of network adoption that is increasing in the number of depositors that demand ATM services and the extent of retail orientation, and decreasing in the size of a bank's proprietary ATM network. The results also support the idea that the adoption of shared electronic banking network is a rational economic decision, i.e., the greater the perceived business value of network membership, the earlier the adoption.

Our findings are similar to those reported by Hannan and McDowell (1984) and Saloner and Shepard (1991), who investigated the adoption of ATM technology. However, we find that the number of bank branches registered a negative impact on early adoption, which is contrary to the finding by Saloner and Shepard (1991), in which the number of bank branches is a proxy for the proprietary network benefits. Our result suggests that the size of the proprietary network is associated with high opportunity costs of shared network adoption. A recent interview with the president of New England Network Inc. confirmed this finding ${ }^{1}$.

This study offers some useful methodological ideas for senior management. The chief executive officer at our sponsoring organization is currently rolling out a large debit card program in the New England area. The marketing effort involves approaching and convincing firms that have not yet done so to adopt point-of-sale debit technology, as an alternate method of payment for their customers. Knowledge of the key drivers that lead to adoption of this related technology will be an important ingredient in the success of the

\footnotetext{
${ }^{1}$ Personal communication with Richard Yanak, President, Yankee 24/New England Network Inc., Wallingford, Connecticut.
} 
program, because it will enable network marketing staff members to focus on the "right" segment first -- the innovators and early adopters, and then the early majority.

Although the context of this study is shared electronic banking networks, the examination of the adoption of a single technology in a single industry avoids the difficulties encountered in many previous research in controlling for differences across innovations in capital costs and/or potential profitability (Hannan and McDowell, 1984; Rose and Joskow, 1990). The results of this study may have implications for other IOSs, such as nationally shared electronic funds transfer networks, securities settlement systems, credit card switching and transaction confirmation systems, and SWIFT.

\subsection{Limitations and Future Research}

Several shortcomings and limitations of this study should be acknowledged. Because we studied one very large network (Yankee 24) in one limited region of the United States (New England), the generalizability of the results is limited. The reader should not assume that our results can be generalized to the case of adoption of shared electronic banking networks in other regions of the U.S., or to other countries, such as France, the United Kingdom or Japan, where electronic banking is a mature business for most banks. We are presently undertaking additional research to examine the differences (Kauffman, in process).

Due to the limited availability of data and the inability of the probit model to handle time-varying variables, we were only able to examine the impact of a subset of variables that are likely to influence the net benefits of network adoption. For example, further study should incorporate pricing and cost of input variables.

The economic approach employed in this study may be limited because it is theoretically indifferent to institutional factors on either the supply or demand side (Brown, 1981). By focusing solely on the perceived business value of network adoption, it ignores non-monetary factors that may potentially affect adoption decisions, such as patterns of 
communication and influence (Rogers, 1983), organizational structure and decision hierarchy, technical know-how and organizational learning (Attewell, 1992), innovation champions inside the adopting firm, inter-firm linkage and power relationships, and the supply-side competitive environment and the structural characteristics of the adopter industry (Robertson and Gatignon, 1986), which were not present in the data set.

In addition, network externalities, well known in economics literature as the value of a network created as a by-product of an existing installed base, may be an important source of business value that may influence the valuation and adoption of shared electronic banking networks. Because probit model is not rich enough to incorporate time-varying covariates, such as the growth of the network installed base, additional research may employ a more sophisticated econometric model to measure the actual extent cf network business value externalities and their impact on the timing of adoption. 


\section{References}

Attewell, P. (1992), "Technology Diffusion and Organizational Learning: The Case of Business Computing," Organization Science, Vol. 3, No. 1 (February), 1-19.

Bakos, Y. J. (1991), "Information Links and Electronic Marketplaces: The Role of Interorganizational Information Systems in Vertical Markets," Journal of Management Information Systems, Vol. 8, No. 2 (Fall), 31-52.

Banker, R. D. and R. J. Kauffman (1991), "A Case Study of Electronic Banking Operations at Meridian Bancorp," Information and Software Technology, Vol. 33, No. 3 (April), 200-204.

Banker, R. D. and R. J. Kauffman (1991), "Quantifying the Buisiness Value of Information Technology: An Illustration of the 'Business Value Linkage' Framework," Working Paper (March), Center for Research on Information Systems, Stern School of Business, New York University.

Bass, F. M. (1969), "A New Product Growth Model for Consumer Durables," Management Science, Vol. 15, No. 1 (January), 215-227.

Brancheau, J. C. and J. C. Wetherbe (1990), "The Adoption of Spreadsheet Software: Testing Innovation Diffusion Theory in the Context of End-User Computing," Information Systems Research, Vol. 1, No. 2 (June), 115-143.

Brown, L. (1981), Innovation Diffusion, London: Methuen.

Canright, C. (1988), "Seizing the Electronic Information Advantage," Business Marketing (January), 81-86.

Cash, J. and B. Konsynski (1985), "IS Redraws Competitive Boundaries," Harvard Business Review, Vol. 62, No. 2 (Jan.-Feb.), 134-142.

Clemons, E. K. (1990), "MAC-Philadelphia National Bank's Strategic Venture in Shared ATM Networks," Journal of Management Information Systems, Vol. 6, No. 5 (Summer), 5-25.

Clemons, E. and M. Row (1988), "McKesson Drug Company: A Case Study of Economost-A Strategic Information System," Journal of Management Information Systems, Vol. 5, No. 1 (Summer), 36-50.

Cohen, W. M. and D. A. Levinthal (1990), "Absorptive Capacity: A New Perspective on Learning and Innovation," Administrative Science Quarterly, Vol. 35, No. 1 (March), 128-156.

Copeland D. G. and J. L. McKenney (1988), "Airline Reservations Systems: Lessons from History," MIS Quarterly, Vol. 12, No. 3 (September), 353-370. 
Croxford, H. (1988), "Taking Sharing Way Beyond ATMs", Bank Network News, Vol. 7, No. 6 (August 14), 4-5.

Davies, S. (1979), The Diffusion of Process Innovation, Cambridge, MA: Cambridge University Press.

Farrell, J. and G. Saloner (1985), "Standardization, Compatibility, and Innovation," Rand Journal of Economics, Vol. 16, No. 1 (Spring), 70-83.

Farrell, J. and G. Saloner (1986), "Installed Base and Compatibility: Innovation, Product Preannouncements, and Predation," American Economic Review, Vol. 76, No. 5 (December), 940-955.

Felgran, S. C. and R. E. Ferguson (1986), "The Evolution of Retail EFT Networks," New England Economic Review (July-August), 42-56.

Gaski, J. F. (1984), "The Theory of Power and Conflict in Channels of Distribution," Journal of Marketing, Vol. 48 (Summer), 9-29.

Glaser, P. F. (1988), "Using Technology for Competitive Advantage: The ATM Experience at Citicorp," Managing Innovation: Cases from the Service Industries, B. R.

Guile and J. B. Quinn (editors), National Academy Press, 108-114.

Greene, W. H. (1990), Econometric Analysis, New York: MacMillan Publishing Company.

Hannan, T. and J. McDowell (1984), "The Determinants of Technology Adoption: The Case of the Banking Firm," Rand Journal of Economics, Vol. 15, No. 3 (Autumn), 328-335.

Jensen, R. (1982), "Adoption and Diffusion of an Innovation of Uncertain Profitability," Journal of Economic Theory, Vol. 27, 182-193.

Johnston, H. R. and M. R. Vitale (1988), "Creating Competitive Advantage with Interorganizational Information Systems," MIS Quarterly, Vol. 12, No. 2 (June), 153-165.

Katz, M. and C. Shapiro (1985), "Network Externalities, Competition, and Compatibility," American Economic Review, Vol. 75, No. 3 (June), 424-440.

Katz, M. and C. Shapiro (1986a), "Technology Adoption in the Presence of Network Externalities," Joumal of Political Economy, Vol. 94, No. 4 (August), 822-841.

Katz, M. and C. Shapiro (1986b), "Product Compatibility Choice in a Market with Technological Progress," Oxford Economic Papers, Vol. 38 (November), 146-165. 
Kauffman, R. J. (in process), "Electronic Banking in Japan," Working Paper, Center for Research on Information Systems, Stern School of Business, New York University.

Kauffman, R. J. and Y. M. Wang (1993), "Growth Patterns and Regime Change in Nationally Shared Electronic Banking Networks: An Econometric Analysis of CIRRUS and PLUS," In Proceedings of the 25th Hawaii Intemational Conference on Systems Science. Vol. IV. IEEE Computer Society (January), 819-828.

Mahajan, V., E. Muller, and R. K. Srivastava (1990), "Determination of Adopter Categories by Using Innovation Diffusion Models," Journal of Marketing Research, Vol. 27, No. 1 (February), 37-55.

Mansfield, E. (1968), Industrial Research and Technological Innovation, New York: W. W. Norton and Co.

Mansfield, E. (1993), "The Diffusion of Flexible Manufacturing Systems in Japan, Europe and the United States," Management Science, Vol. 39, No. 2 (February), 149-159.

Markus, M. L. (1987), "Toward a Critical Mass Theory of Interactive Media: Universal Access, Interdependence and Diffusion," Communication Research, Vol. 14, No. 5 (October), 491-511.

McAndrews, J. J. (1991), "The Evolution of Shared ATM Networks," Business Review, Federal Reserve Bank of Philadelphia (May-June), 3-16.

McAndrews, J. J. (1992), "Results of a Survey of ATM Network Pricing," Working Paper, No. 92-7 (April), Federal Reserve Bank of Philadelphia.

Mohr, L. B. (1982), Explaining Organizational Behavior, San Francisco: Jossey Bass.

O'Callaghan, R., P. J. Kaufmann, and B. R. Konsynski (1992), "Adoption Correlates and Share Effects of Electronic Data Interchange Systems in Marketing Channels," Journal of Marketing, Vol. 56, No. 2 (April), 45-56.

Pennings, J. M. and F. Harianto (1992), "The Diffusion of Technological Innovation in the Commercial Banking Industry," Strategic Management Journal, Vol. 13, 29-46.

Polk's Bank Directory: Sectional Issue, Vol. 186 (Fall 1987), Nashville: R.L. Polk \& Co.

Robertson T. S. and H. Gatignon (1986), "Competitive Effects on Technology Diffusion," Journal of Marketing, Vol. 50, No. 3 (July), 1-12.

Rogers, E. M. (1983), Diffusion of Innovations, New York: Free Press. 
Rohlfs, J. (1974), "A Theory of Interdependent Demand for a Communication Service," Bell Journal of Economics and Management Science, Vol. 5, No. 1, 16-37.

Romeo, A. (1977), "Interindustry and Interfirm Differences in the Rate of Diffusion of an Innovation," Review of Economics and Statistics, Vol. 57, No. 3, 311-319.

Rose, N. and P. Joskow (1990), "The Diffusion of New Technologies: Evidence from the Electric Utility Industry," Rand Journal of Economics, Vol. 21, No. 3, (Autumn), 354-374.

Saloner, G. and A. Shepard (1991), "Adoption of Technologies with Network Effects: An Empirical Examination of the Adoption of Automated Teller Machines," Working Paper No. 577 (April), Sloan School of Management, Massachusetts Institute of Technology.

Steiner, T. and D. Teixeira (1990), Technology in Banking: Creating Value and Destroying Profits, New York: Dow Jones - Irwin.

Tornatzky, L. G. and R. J. Klein (1982), "Innovation Characteristics and Innovation Adoption-Implementation: A Meta-Analysis of Findings," IEEE Transactions on Engineering Management, Vol. 29, No. 11, 28-45.

Weiss, D. M. (1986), After the Trade is Made: Processing Securities Transactions, New York: New York Institute of Finance/Simon and Schuster. 